\section{Homosexuality and biomarkers of aging in the production of gerontological knowledge by American, British, and Brazilian authors}

\author{
Homossexualidade e biomarcadores de \\ envelhecimento na produção de conhecimento \\ gerontológico por autores estadunidenses, \\ britânicos e brasileiros
}

Homosexualidad y biomarcadores de envejecimiento en la producción de conocimiento gerontológico, según autores estadounidenses, británicos y brasileños 


\section{Introduction}

Since the late 1960s, studies in gerontology have addressed male homosexuality 1,2,3,4. In different areas of knowledge (from biomedicine to social psychology), "positive" markers of old age have emerged, which meanings were based on a binary discourse about life, social relations, and selfpolarizing heteronormative representations 2,3 , grasping on the futurity ideal, mainly by emphasizing monogamy, marriage, reproduction, and the nuclear family, as well as pathologizing sexual and affective relations with the same sex, whether in psychiatric or epidemiological terms.

This article aims to analyze the representations of homosexual aging arising from scientific production in gerontology from three different national contexts: Brazil, the United States, and the United Kingdom. The objective is to identify and describe the produced aging markers, analyzing the production from 1960 to 2018, based on a combined literature review assessed by the R software tools. Using the collected biomarkers, this study aims to identify sociologically the representations of old age and aging in studies on homosexuality, articulating a historical and comparative analysis from the first publications.

Biomarkers - understood as a set of descriptors reproduced and repeated in the publications enable the understanding of distinguish topics regarding gender, sexuality, health, generation, social class, etc., which may converge in social representations regarding homosexual old age in the analyzed production. The term "gerontology" is a posthumous methodological appropriation, as an "umbrella term", which brings together studies on old age and aging, converging different areas of knowledge including studies that were not recognized as gerontological until the mid-1960s/1980s - because the formation of this (sub)area is recent in historical terms, as discussed in the next topic.

\section{Brief history}

\section{The birth of gerontology and the new "life sciences"}

Since the second half of the 20th century, the new "life sciences" - especially biotechnology, pharmacology, demography, physiology, and genetics - have emerged as knowledge specialties, linked to Western economic and population interests in the post-World War II. According to the British sociologist and economist Nikolas Rose 5 , the body has become a privileged locus of study on an epithelial and psychosomatic scale. Thus, biological life has become a "vital focus of specific government forms, targeting new mechanisms of authority and expertise, a highly catalytic field for knowledge, expanding territory for bioeconomic exploration, an organizing principle of ethics, and a bet on a policy of molecular life" 5 (p. 17).

This change implies the branching of classical biological sciences and the birth of complementary disciplines/specialties, also leading to the development of biological markers, which can identify subjects, habits, and life forms 6,7,8. These markers produce and name life forms which, according to Donna Haraway 8 and Carlos Novas 9 , are treated and partially assimilated in diverse terms, including the demands of academic and political movements on the margins of mainstream medical research in the mid-1970s and 1980s. In this context, there was a rise in feminist and homosexual movements, whether due to waves of critical studies that created reflections about desires, bodies, and other possible ways of representing oneself, or by the hardening of some categories used to name subjects and practices in the medical and psychological fields, such as "elderhood", "elderly", "homosexual", and "disabled", for example 5,8,10,11,12.

Gerontology, which genealogy dates back to the union between knowledge from the medical sciences and social psychology at the end of the 19th century 13, developed as a field of academic research only in the second half of the following century. This was a response to the populational problematic faced in the advanced liberal democracies, incorporating a marketing discourse, which created a meaning for the expression "the elderly": a powerful field of scientific production and professional speculation 13,14 - a more affectionate term for professional middle class subjects with significant economic and cultural capital.

According to the American anthropologist Lawrence Cohen 15, gerontological narratives in the West speculated on "old age" as a priori problem, from a vocabulary full of biological and social 
assumptions. The common place of old age in gerontological discourse and the repeated attempts to homogenize the social and individual processes of old age reveal the paradoxes of recognizing internal and external heterogeneities, which often produce the tautological standardized old age and aging representations from different perspectives. This place, created by Western gerontology, has globally produced a non-place to the other representations developed in other contexts, as analyzed by Cohen 15 regarding the Indian old age.

In Problems of Aging - a publication developed from the first conference on aging and reproduced in 1938 by the U.S. Department of State - a plan of action was established to deal with the "problems" of old age in many countries. The report discussed the gerontology field, which resembled a missionary specialty, gathering the Western aging model with liberal ethics and with collectively articulated values 15 .

In the 1940s, the Gerontological Society of America and the National Institute on Aging were created to broaden research and professional lines of activity in the country. Bureaucratization and institutionalization of gerontology only occurred in 1978 in the USA, when the State began to recognize the activities that promoted "professional training" in gerontology for public and private university students. The World Assembly on Ageing, held in Vienna (Austria) in 1982, was an extension of what had been planned in terms of the gerontology professionalization since Problems of Aging in North America, and which objective was to link their ideals to a global policy that could reach, above all, underdeveloped countries with an internationalist mission. According to Cohen 15 (p. 73), "international gerontology is therefore the effort to universalize a culturally specific epistemology".

This cultural epistemology, as Cohen 15 highlighted, could be described by six assumptions that hardened the foundations of gerontology at the end of the 20th century, which are: (1) Universality: the recently introduced concept of aging and of universal body remit to the process of bodily aging, therefore, gerontology should also appropriate and produce knowledge; (2) Problematization: the aged body and the older people, in general, would be conceptualized a priori and therefore, treated as "problems" to be assessed and solved; (3) Moral imperative: taking old age and aging bodies as moral problems; (4) Threat: the "problem" of old age understood not only as an analysis question, but fundamentally as a threatening condition, combined with a metanarrative of "(a)normality" and "(dis) functionality"; (5) Possibility for coercion: the coexistence of problematic discourses and (a)normality simultaneously allows the occurrence of contradictory expressions in the gerontological practice, whether, for example, activism or age discrimination, or autonomy or coercion; and (6) Reification of ambiguity: ambiguity is maintained as a critical condition of old age, grouping not only its dilemmas and paradoxes but also closing the possibility of its criticism.

From the geopolitical perspective, gerontology in North America and Europe is consolidated around a scientific agenda that could be internationally replicated; however, it is noted that it is organized, mostly, by developed countries, which may be incorporated in the alliance between the USA and the great European liberal powers. The Western advanced liberal democracies appear at first as a problem in this context, since they concentrate the highest aging indicators in demographic terms. But they are also a "successful" solution, which, copes with the "challenges" posed by old age, as a model to be reproduced in underdeveloped democratic and liberal countries, as in Brazil, for example 16 .

In addition to international conferences and treaties on old age, markers of "successful" aging and their correlated representations have also emerged in the academic literature, linking social well-being concepts to a neoliberal policy around vitality and hope 5,17, as well as showing a significant increase in the biotechnological and pharmacological possibilities of intervention, monitoring, and government of populations/groups 5,12 - among them, homosexual subjects. In any case, as this article discusses, the recognition and inclusion of homosexuality occurred progressively from an epidemiological perspective, in which the success or failure of elderly homosexuals was measured and compared to parameters regarding biomarkers from the pathology and virology fields, which go back to the period of the HIV/AIDS epidemic onset and spread. Moreover, by contrast, the findings of this study show how failure or relative failure of certain old age amplifies the success of others without comparative parameters being questioned in their ethnocentrism or tendencies with respect to gender or sexual orientation. 
Since the 1970s, homosexuality representations in gerontological studies have advertised contradictory and paradoxical intelligibilities, sometimes emphasizing the precarious and tragic character of this type of old age, or reinforcing an idealized perspective associated to modelling patterns of body, sexuality, and sociability 18,19,20,21,22,23,24,25,26. This article analyzes the produced biomarkers of aging, the amount of publications in historical terms (by decade), and journals and areas that produced and published the most studies on the topic "homosexuality", as well as topics assessed in the collected texts - especially those concerning the descriptors "homosexuality", "aging”, and "gerontology" - through a quantitative and qualitative balance of production in Brazil, in the USA, and in the UK.

The concept of representation here is derived from the propositions of the Jamaican-British sociologist Stuart Hall 27, inserted in the sociological perspective of cultural studies. According to Hall 27, the term defines general notions and dichotomous meanings, which implications create intelligibilities by expressions, such as normality/abnormality, right/wrong, healthy/pathological, active/ passive, handsome/ugly, heterosexual/homosexual. They are deeply embedded in power relations, since lives and relationships are shaped by meanings and circumstances, which are dependent on gender binarism, class, color, age, and sexuality 27.

\section{Methods}

The choice of studying the USA and the UK is because the two countries concentrate the highest indicators of scientific production, as well as institutions, studies, and academic publications that first adhered to the gerontological theme of homosexuality, as shown in Figure 1, using a preliminary survey on the quantity of production indexed by country (\%). In Latin America, Brazil has a pioneer role on aging studies, and is currently recognized for the public policies focused in gerontology, such as the Brazilian Policy for the Elderly (1994) and the Brazilian Statute of the Elderly (2003); for having the first gerontology department in a federal university; and for establishing two gerontology courses in public institutions during the 2000s. The University of São Paulo (USP) created the first bachelor's degree in gerontology in 2005, and the Federal University of São Carlos (UFSCar) in 2009.

First, 839 articles were collected from the Web of Science database, which added indexed production with the descriptors "homosexuality", [AND] "aging/ageing", [AND] "gerontology". The search

Figure 1

Indexed gerontological production by country (\%o). World, 1945 to September, 2018.
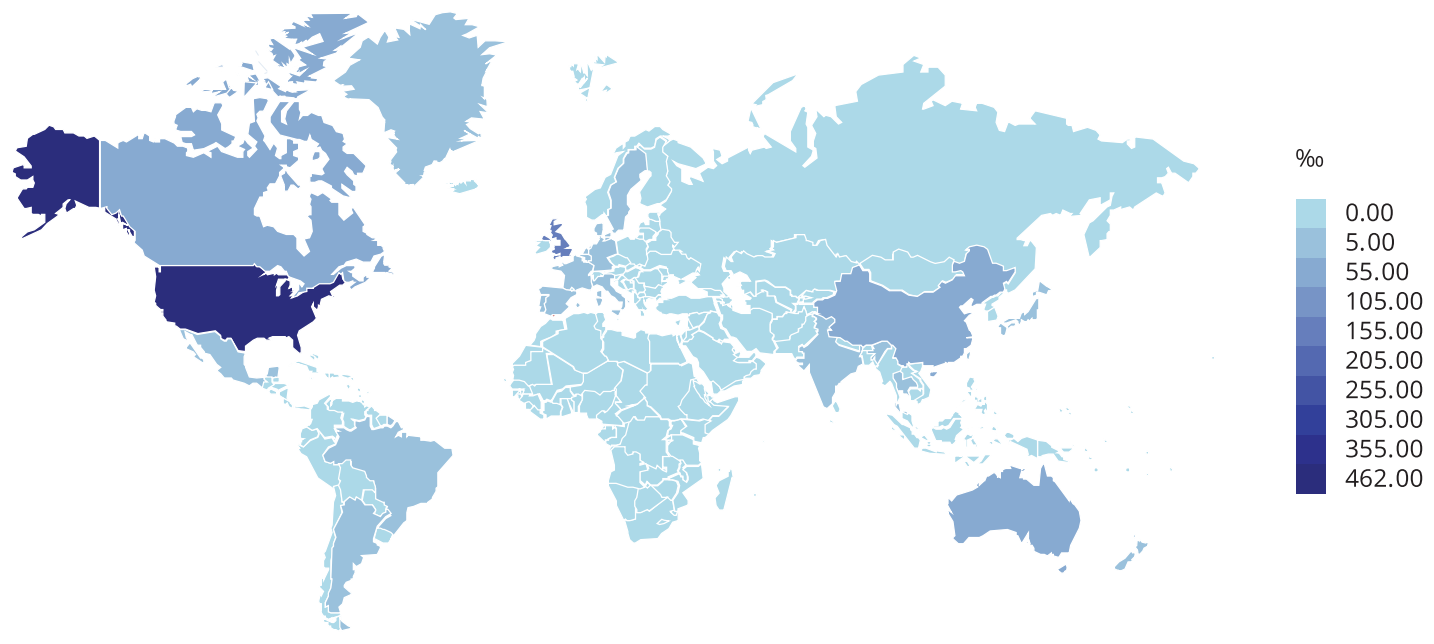
with the AND Boolean operator was combined in three complementary ways: (i) "homosexuality", [AND] "aging/ageing"; (ii) "homosexuality", [AND] "gerontology"; (iii) "homosexuality", [AND] "aging/ ageing", [AND] "gerontology". The collected publications comprises articles produced and published between 1970 and September, 2018 from 47 research areas/subareas, which are the following: Behavioral Sciences, Infectious Diseases, Immunology, Public Environmental Occupational Health, Psychology, Reproductive Biology, Geriatrics Gerontology, Health Care Sciences Services, Demography, Research Experimental Medicine, Microbiology, Virology, Science Technology Other Topics, Pharmacology Pharmacy, Sociology, Pathology, Toxicology, Gastroenterology Hepatology, Psychiatry, Urology Nephrology, Substance Abuse, Hematology, Genetics Heredity, Physiology, Social Sciences Other Topics, Social Issues, General Internal Medicine, Respiratory System, Anthropology, Oncology, Biomedical Social Sciences, Obstetrics Gynecology, Ethnic Studies, Neurosciences Neurology, Mathematical Computational Biology, Education Educational Research, Computer Science, Life Sciences Biomedicine Other Topics, Family Studies, Business Economics, Endocrinology Metabolism, Communication, Cardiovascular System Cardiology, Surgery, Evolutionary Biology, Urban Studies, and Dermatology (Figure 2).

In order to analyze the abstracts and main texts, the Text Mining 28 and the SnowBallC 29 packages were used, applied to the R software, version 3.5.0 (http://www.r-project.org). Word clouds and comparative clouds 30 were created and included titles, abstracts, and body of the texts to represent the frequency of the keywords that appeared, identifying the most common words. Correspondence Analysis 31 was used to develop perceptual maps, and Sentiment Analysis (or opinion mining) 32 to assessed the emotions expressed in the texts, based on positive and/or negative used expressions.

The "homosexual" term is maintained and considered as the descriptor for homosexual relations among men, instead of "gay". For many reasons, "gay" has a different meaning in terms of representation (including a perspective organized and fixed by market and consumption imperatives). Moreover, the term does not gather the same understanding and use for gerontological and biomedical studies, since these fields have historically considered same-sex relations between men as "homosexuality" and mostly identified them as "homosexual subject(s)". However, as sociological categories, "homosexuality" and "homosexual" must be understood in their particularities and subject to criticisms in gerontological and biomedical sciences, as this article analyzed in the discussion section.

\section{Results}

\section{A balance of scientific representations from the 1970s to September, 2018}

By the characterization of the production concerning the type of journal, this study observed the most common: PLoS One (9.9\%), Sexually Transmitted Diseases (8\%), and Sexually Transmitted Infections (7.2\%). In total, the journals represent $63.1 \%$ of the produced articles. Most produced articles came from the 2010s $(78,4 \% ; n=625)$.

The ten areas concentrating the largest production amount were the following, in descending order: (1st) Behavioral Sciences ( $n=765)$, (2nd) Infectious Diseases ( $n=677)$, (3rd) Immunology ( $n=636$ ), (4th) Public Environmental Occupational ( $n=526$ ), (5th) Psychology ( $n=520)$, (6th) Reproductive Biology ( $n=514)$, (7th) Geriatrics Gerontology $(n=440)$, (8th) Health Care Sciences Services $(n=346)$, (9th) Demography $(\mathrm{n}=313)$, and (10th) Research Experimental Medicine $(\mathrm{n}=225)$ (Figure 2).

\section{- Titles}

Figure 3 shows the most used words in the titles of the articles, in general. Figure 4 shows the most used words in titles per decade. From the results, 9,362 terms were found in the titles of the articles in general, whereby $48(0.51 \%)$ correspond to the 1970s, $123(1.31 \%)$ to the 1980 s, $227(2.42 \%)$ to the 1990 s, $1,350(14.42 \%)$ to the 2000 s, and 7,562 (80.77\%) to the 2010s. The five most frequent words/ terms were: "men", "HIV", "sex", "among", and "sexual". Together, these words represent $20.5 \%$ of the terms used in the titles of articles. 
Figure 2

Indexed gerontological production by and research area, with repetition, in absolute numbers. World, 1945 to September, 2018

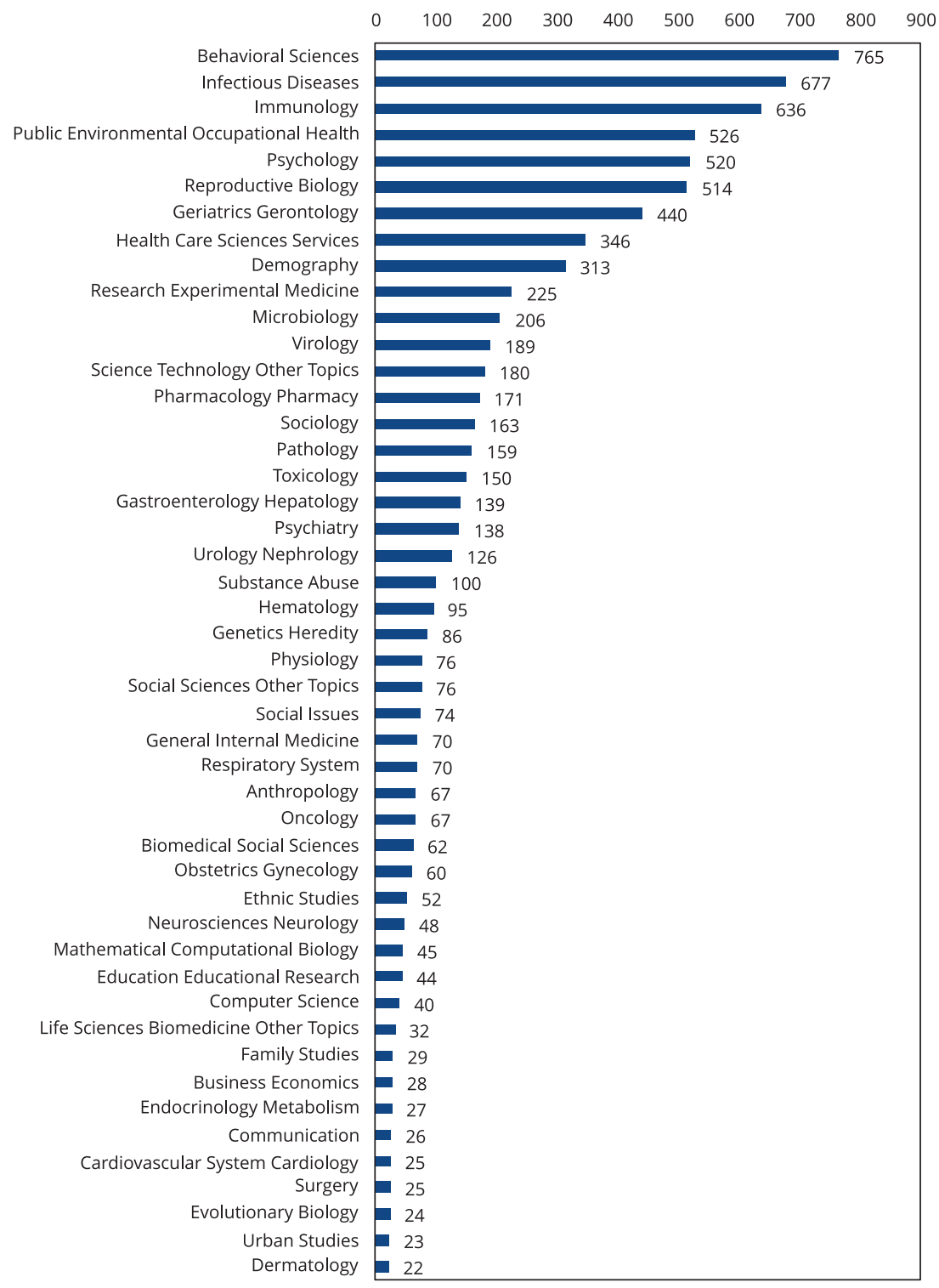

Thus, homosexuality often appears as an epidemiological problem rather than a phenomenon also associated with other mental health problems, such as depression caused by continuous exposure to diverse discrimination and prejudice forms, as well as suicides, loss of a social support in old age, neurological limitations and deficits resulting from stressful events, and harmful to social, economic, or physical integrity.

There is also a prevalence of terms that repeatedly reiterate male homosexuality, such as "men", "MSM", and "gay" (Figure 3). The main aspect of male homosexuality from 1970 to the present, which emphasis on these three descriptors, enabled the understanding of two perspective points of represen- 


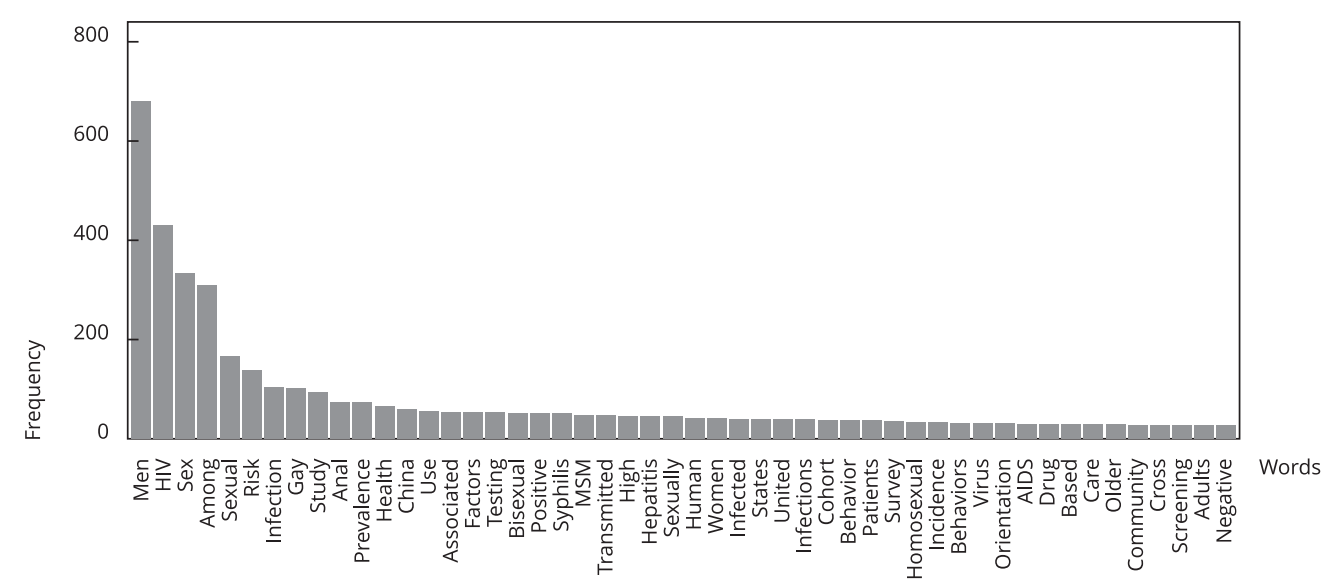

tations about homosexuality in academic production: first, there is a removal of the sexual sphere of lesbian and transsexual women, at the same time a hypersexualized notion of relationships among men is disseminated, prevailing an understanding of sexual behavior almost exclusively associated to sex.

Regarding the Sentiment Analysis, the terms considered "positive" and those considered "negative" were grouped. The data showed there was a predominance of "negative" terms in the production of gerontological knowledge, especially regarding the impact of the HIV/AIDS epidemic in the 1980s and 1990s, showing there was a change in the studied themes and topics since the virus spread (Figure 5). The terms, therefore, reveal the focus of production, which was the sexual understanding of desire, ignoring, among other things, the loving and affective sphere of relationships.

The focus around sexual representations, especially since the 1980s, is symptomatic of the sexual panic of AIDS, which marks a shift in scientific and social terms regarding homosexuality. By 1973 there was an association of homosexuality with mental disorder (or psychiatric disorder). With the depsychiatrization of homosexuality - called "homosexualism" at that time - there was a change in terms of vocabulary and representation of same-sex sexual relations, whereas homosexuality, from the HIV/AIDS epidemic, is now recognized as an epidemiological threat.

\section{- Abstracts}

The articles from the 1970s and 1980s lacked available abstracts, therefore this study only analyzed data regarding the 1990s, 2000s, and 2010s. This study found 102,170 terms in the abstracts of the articles in general, in which 1,029 (1.01\%) were regarding articles from the 1990s, 14,847 (14.53\%) from the 2000s and 86,294 (84.46\%) from the 2010s. Overall, the five most frequent words were: "HIV”, “men”, "MSM”, “sex”, and "among” (Table 1).

From the Sentiment Analysis, there were 7,233 correspondences between the words in the texts, of which 2,124 corresponded to "positive" sentiments and 5,109 corresponded to "negative" sentiments. The five most frequent words regarding Positive Sentiments were: "important", "receptive”, "well", "support", and "effective" - together they represent $20.1 \%$ of the found positive sentiments. The five words regarding Negative Sentiments were: "risk", "infection”, "infected”, "cancer", and "virus" - together they represent $53.5 \%$ of the found negative sentiments. The prevalence of negative descriptors still shows a vocabulary closer to the pathology and epidemiology field descriptors, whose meanings may be associated with a moralizing view that recognizes homosexual old age as something 


\section{Figure 4}

Most frequent words in the titles of articles, by decade. Brazil, United States, and United Kingdom, 1970 to September, 2018.

4a) $1970 \mathrm{~s}$

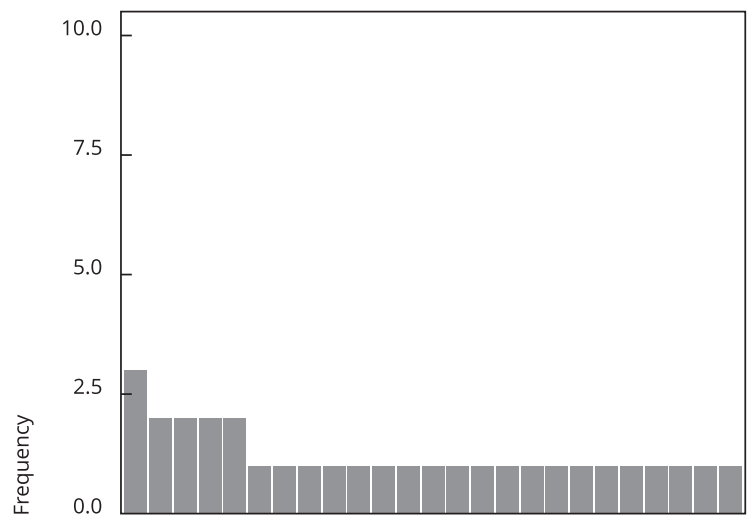

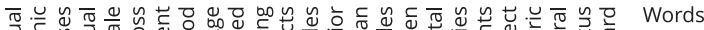

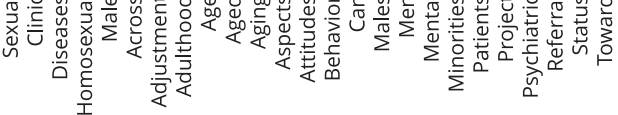

4c) $1990 \mathrm{~s}$

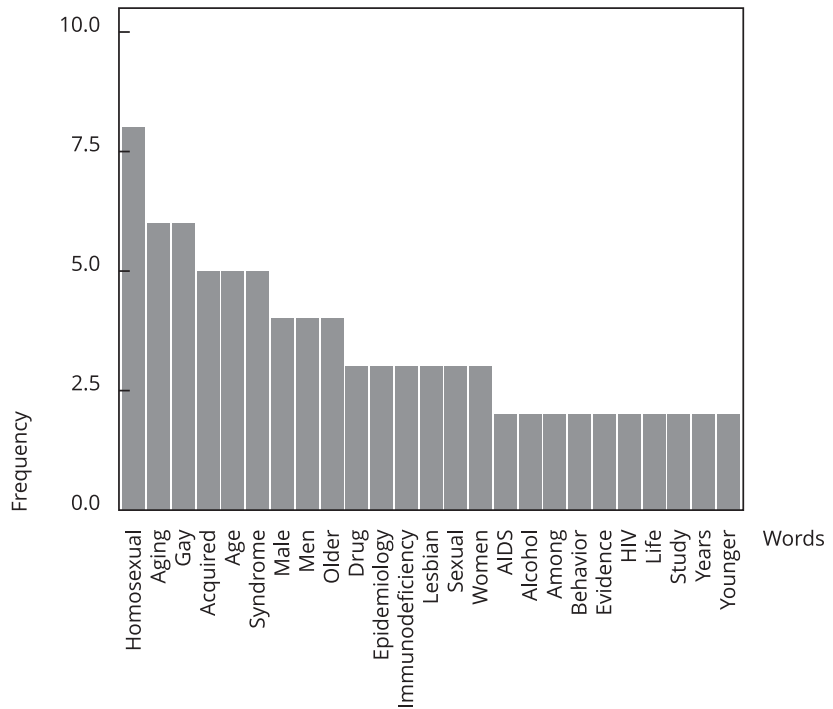

4e) $2010 \mathrm{~s}$

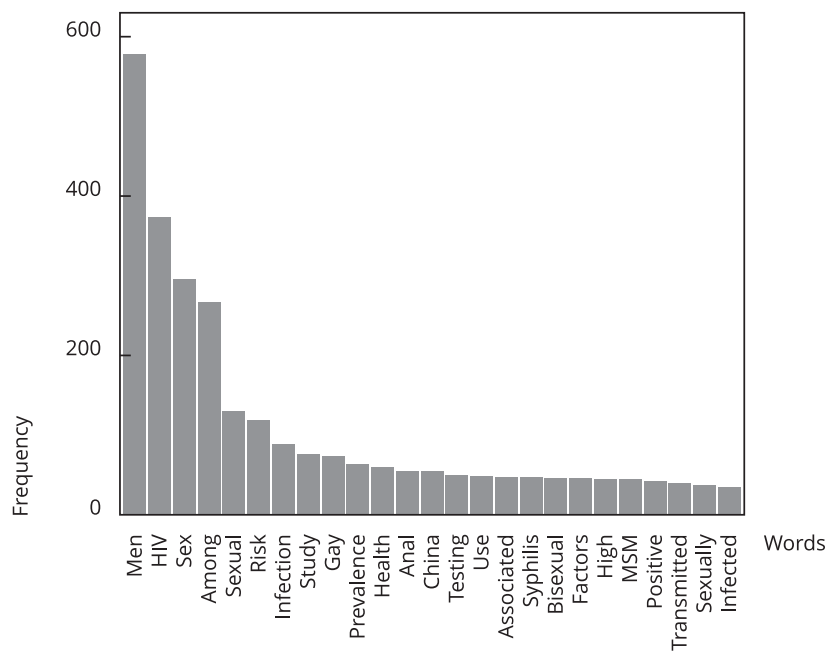

4b) $1980 \mathrm{~s}$

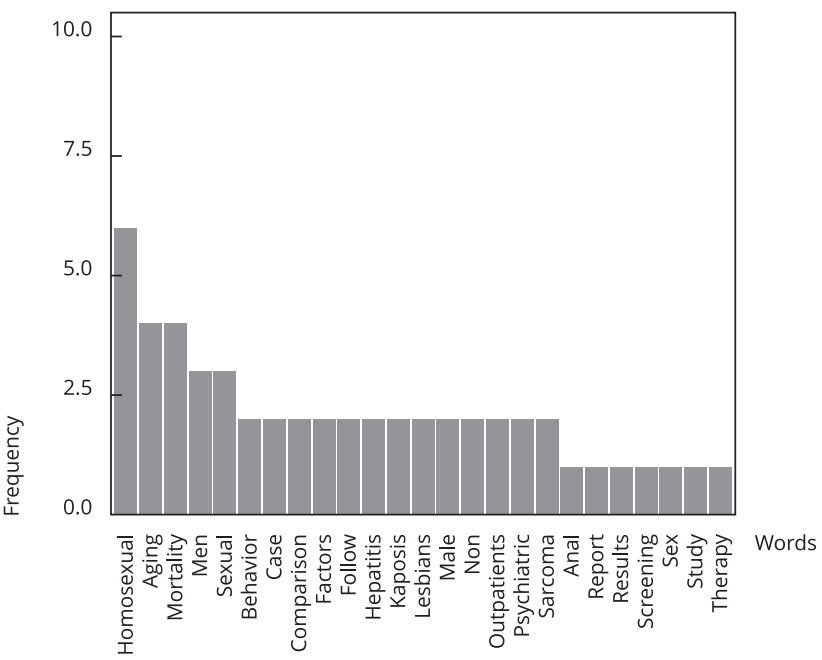

4d) $2000 \mathrm{~s}$

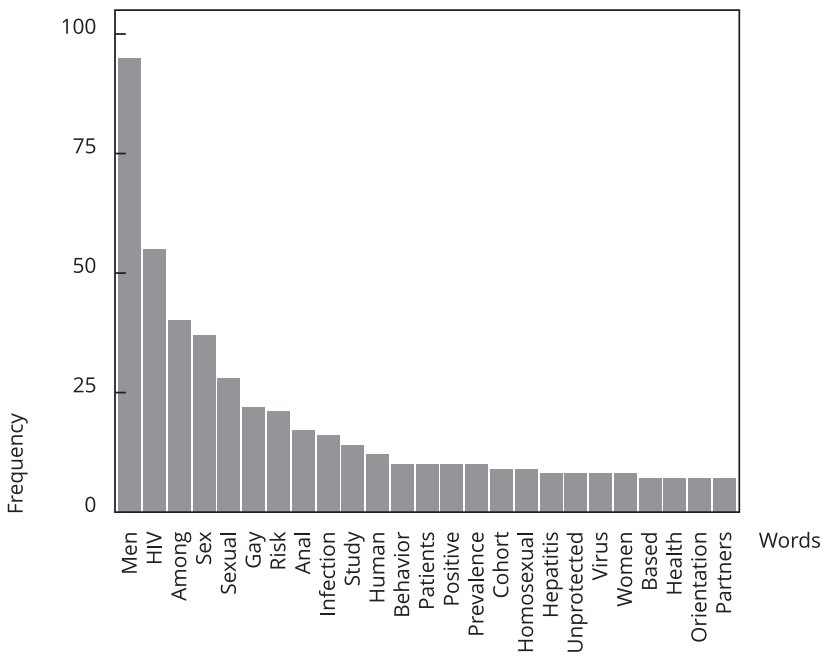




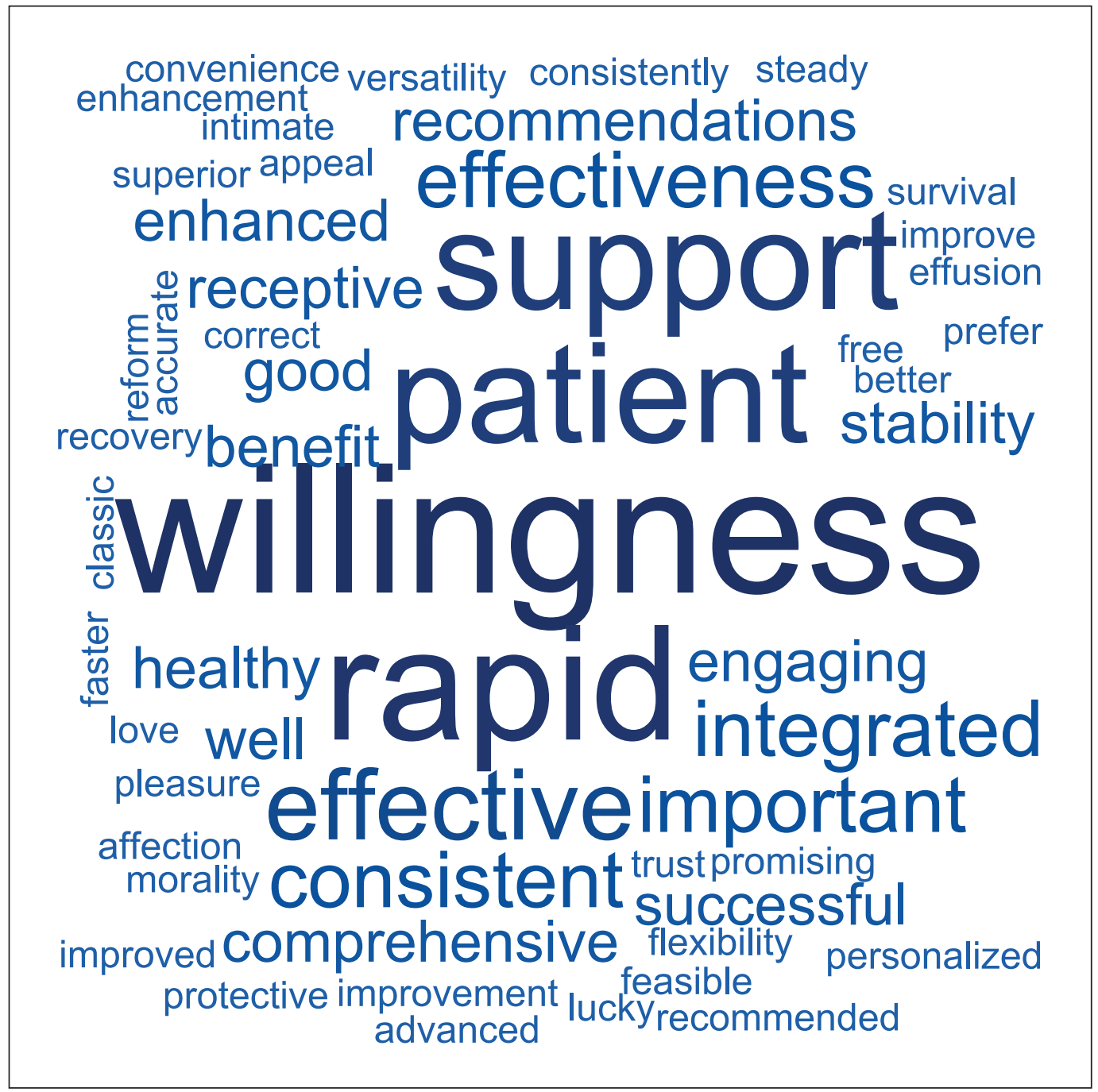

(continues)

negative. Thus, by continually emphasizing pathological aspects of sexuality, these descriptors contribute to the discrimination and prejudice processes in homosexual old age.

From these abstracts it was discovered that the studied articles tend to associate middle aged men and older people with HIV/AIDS, infection, risk, and predominantly, with the sexual sphere. The removal of other issues/spheres inherent in aging and old age may be understood as a response of the new medical sciences to the sexual-moral panic of AIDS, with an articulation in the gerontology production, as the data corroborate.

Therefore, there is a hyper-sexualization of homosexual men in gerontology, as if they had no other health problems, issues regarding sociability, and affective and emotional dilemmas throughout their life. This fact may be understood even with the performed association analysis, which discov- 


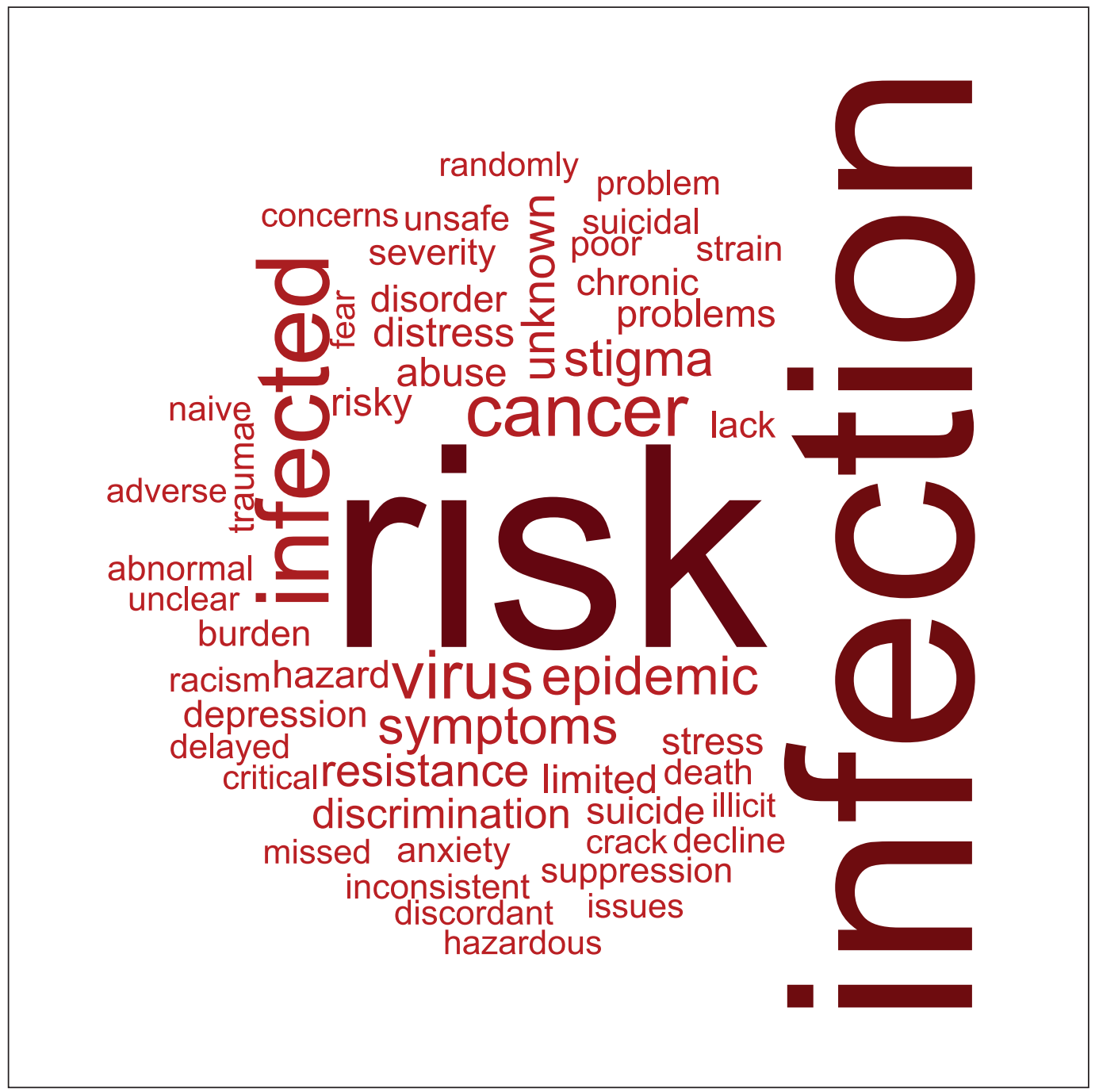

(continues)

ered which terms were grouped with the most prevalent descriptors in the abstracts, as the following: "HIV", "men”, "MSM", "sex", and "among”. Table 2 presents an association analysis between the most frequent terms in the abstracts. The values range from 0 to 1 , the amount understood as the strength of the association between terms. For example, if the correlation equals 1, it means that two terms were used together in $100 \%$ of the texts, whereas if the correlation was 0.50 , two terms were used together in $50 \%$ of the texts.

The epidemic repositioned the social understanding on homosexuality, failing to recognize the issues regarding sociability, as well as networks and social support, as the data indicate. Although a possible scientific caution may be inferred in the little attention paid to mental health, since associating homosexuality to it could induce its association as a psychiatric disorder, the fact is that the studies on homosexual old age reinforced the social representations that have made male homosexuality almost synonymous with AIDS in the 1980s 33,34,35,36,37. 


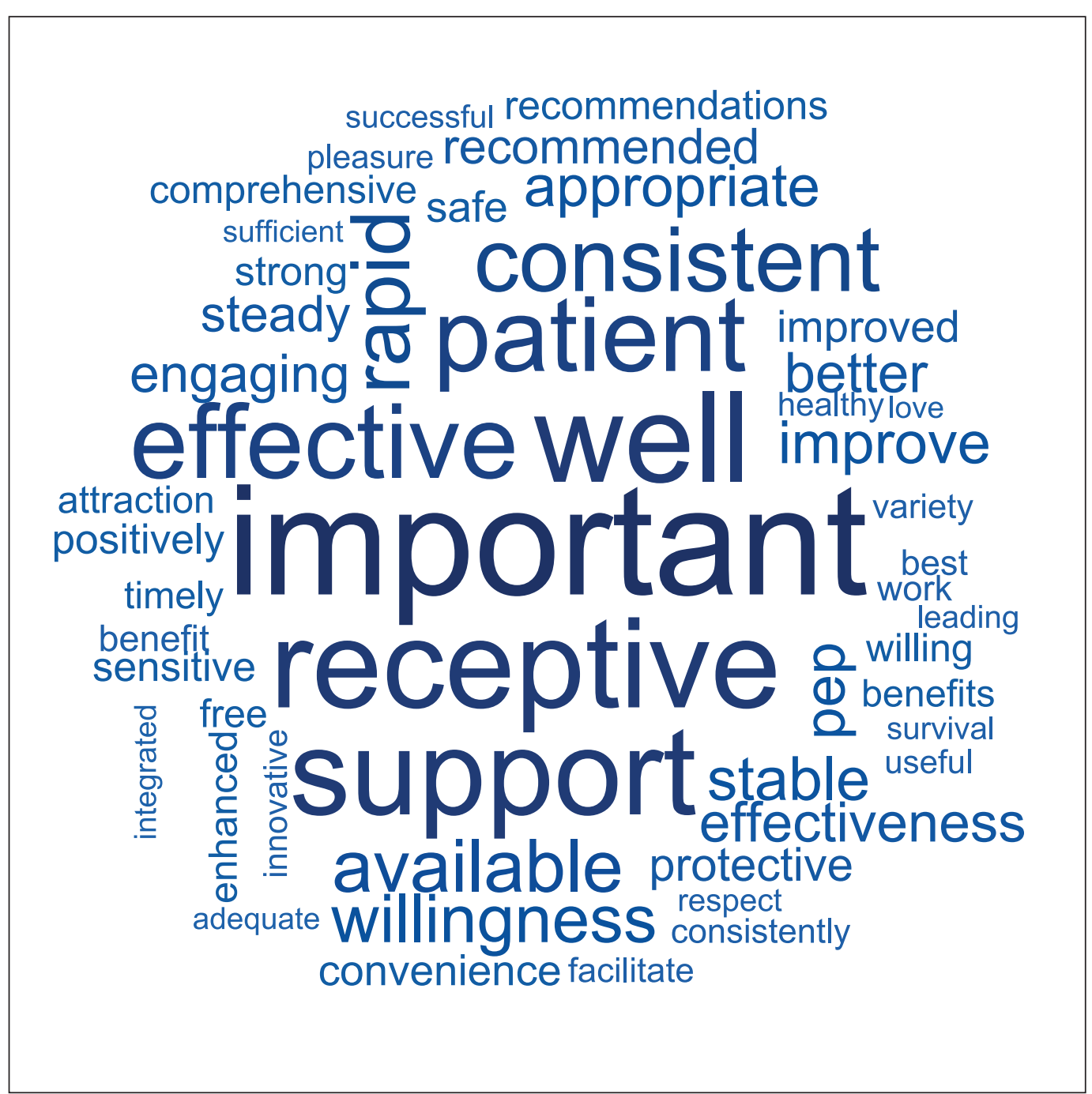

(continues)

\section{Discussion}

\section{The sexual panic of AIDS and the representational cut of male homosexuality}

Based on the produced and presented data in the previous topic, this article starts its discussion with the following question: what reasons are there for the AIDS predominance in the production of gerontological knowledge on homosexuality? The first reason considered concerns the invention of risk groups by epidemiology. According to Susan Sontag 35 and Michel Pollak 33, the term "risk group" (or "exposed group") has been present in the medical literature since the earliest records of HIV/AIDS cases.

According to Pollak 33, the association between specific social groups and AIDS preceded a clinical profile, resulting in a biologically questionable correlation about subjects, lifestyles, and sexual 


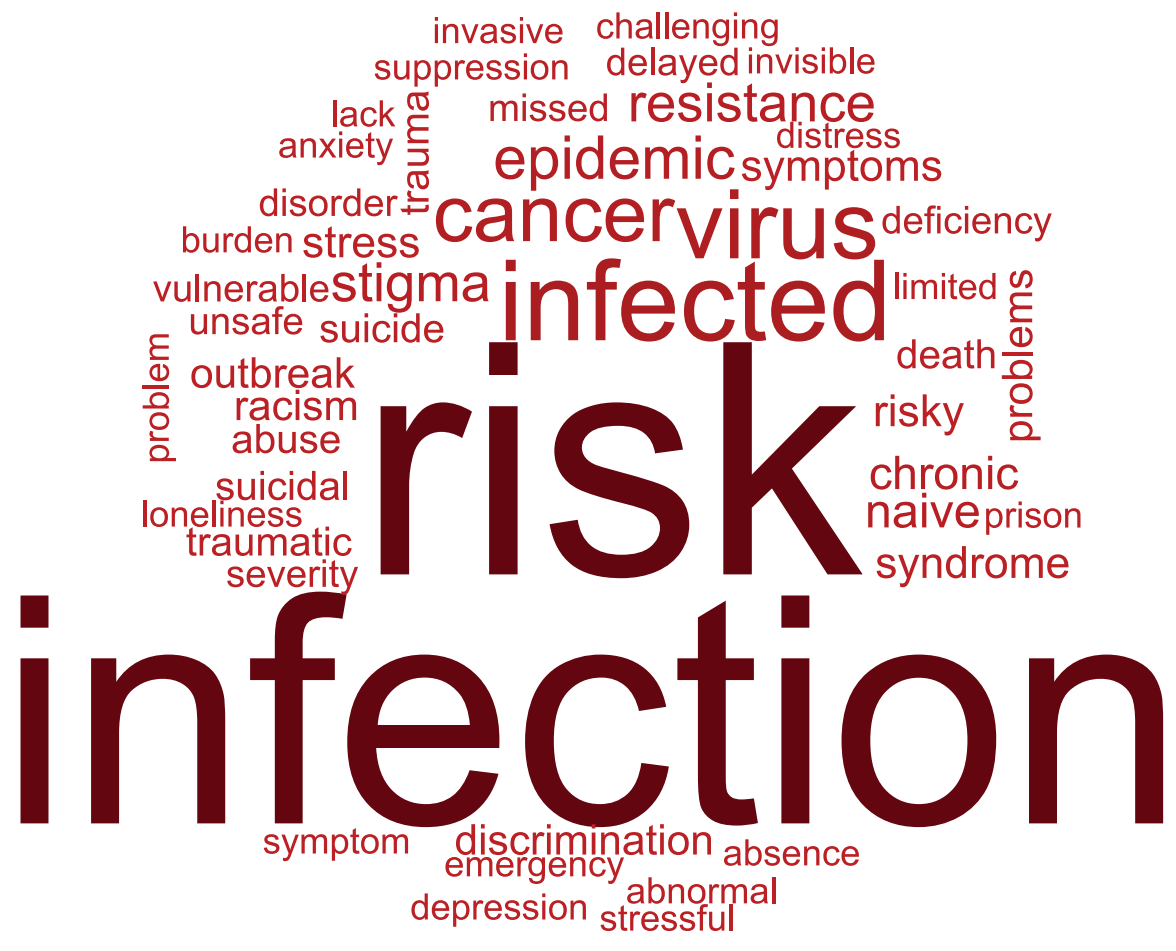

practices. The publication of Kaposi's sarcoma and Pneumocystis carinii cases since 1981 has created a strict vigilance for socially stigmatized groups, including homosexuals, intravenous drug abusers, Haitian immigrants, and prostitutes.

"From the end of 1981, homosexuals and their 'lifestyle' became the privileged object of researchers from the Centres for Disease Control (CDC), calling into question the use of recreational and euphoric drugs ('poppers', i.e. amyl nitrate), promiscuity, and sodomy (mainly passive): 'According to Dr. Friedmann-Kien, doctors had indicated that the majority of cases were male homosexuals who had frequent and diversified sexual intercourse with multiple partners; up to ten a night, four times a week [...]; in addition, many patients reported using recreational drugs, such as amyl nitrate and LSD, to increase their sexual pleasure'. In November 1981, one could read in a contribution to the First World Congress on Sexually Transmitted Diseases, organized in San Juan: 'The concentration of cases in the group of homosexuals makes the thesis plausible according to which it is convenient to look for the factors of causality in the lifestyle and social environment" 33 (p. 122). 
Table 1

Most frequent words in abstracts of the articles. Brazil, United States, and United Kingdom, 1990 to September, 2018.

\begin{tabular}{|c|c|c|c|c|c|c|c|c|c|c|c|}
\hline \multicolumn{3}{|c|}{ General } & \multicolumn{3}{|l|}{ 1990s } & \multicolumn{3}{|c|}{$2000 s$} & \multicolumn{3}{|c|}{$2010 s$} \\
\hline Word & $\mathbf{n}$ & $\%$ & Word & $\mathbf{n}$ & $\%$ & Word & $\mathbf{n}$ & $\%$ & Word & $\mathbf{n}$ & $\%$ \\
\hline HIV & 3,116 & 3.0 & Age & 34 & 3.3 & HIV & 427 & 2.9 & HIV & 2,678 & 3.1 \\
\hline Men & 2,174 & 2.1 & AIDS & 24 & 2.3 & Men & 391 & 2.6 & Men & 1,764 & 2.0 \\
\hline MSM & 1,717 & 1.7 & Men & 19 & 1.8 & Sexual & 188 & 1.3 & MSM & 1,552 & 1.8 \\
\hline Sex & 1,290 & 1.3 & Male & 14 & 1.4 & Risk & 172 & 1.2 & Sex & 1,121 & 1.3 \\
\hline Among & 1,212 & 1.2 & Time & 12 & 1.2 & Sex & 167 & 1.1 & Among & 1,044 & 1.2 \\
\hline Sexual & 1,157 & 1.1 & Among & 11 & 1.1 & MSM & 165 & 1.1 & Sexual & 967 & 1.1 \\
\hline Risk & 1,057 & 1.0 & HIV & 11 & 1.1 & Among & 157 & 1.1 & Risk & 878 & 1.0 \\
\hline Infection & 732 & 0.7 & Persons & 11 & 1.1 & Anal & 127 & 0.9 & Infection & 629 & 0.7 \\
\hline Anal & 629 & 0.6 & Incidence & 10 & 1.0 & Study & 106 & 0.7 & Associated & 510 & 0.6 \\
\hline Use & 606 & 0.6 & Seroconversion & 10 & 1.0 & Positive & 100 & 0.7 & Use & 510 & 0.6 \\
\hline Study & 603 & 0.6 & Aged & 9 & 0.9 & Infection & 97 & 0.7 & Health & 507 & 0.6 \\
\hline Associated & 567 & 0.6 & Women & 9 & 0.9 & Use & 94 & 0.6 & Anal & 502 & 0.6 \\
\hline Health & 562 & 0.6 & Years & 9 & 0.9 & Results & 89 & 0.6 & Study & 494 & 0.6 \\
\hline Results & 529 & 0.5 & Increase & 9 & 0.9 & Gay & 87 & 0.6 & Testing & 458 & 0.5 \\
\hline Positive & 526 & 0.5 & Cases & 8 & 0.8 & Partners & 83 & 0.6 & Prevalence & 447 & 0.5 \\
\hline Reported & 524 & 0.5 & States & 8 & 0.8 & Reported & 82 & 0.6 & Results & 436 & 0.5 \\
\hline Partners & 509 & 0.5 & United & 8 & 0.8 & Patients & 78 & 0.5 & Reported & 435 & 0.5 \\
\hline Prevalence & 506 & 0.5 & Reported & 7 & 0.7 & Women & 77 & 0.5 & Years & 432 & 0.5 \\
\hline Testing & 506 & 0.5 & Risk & 7 & 0.7 & Age & 74 & 0.5 & Positive & 426 & 0.5 \\
\hline Patients & 503 & 0.5 & Data & 7 & 0.7 & Likely & 62 & 0.4 & Partners & 425 & 0.5 \\
\hline Years & 491 & 0.5 & Distribution & 7 & 0.7 & Prevalence & 59 & 0.4 & Patients & 422 & 0.5 \\
\hline High & 435 & 0.4 & Younger & 7 & 0.7 & Partner & 57 & 0.4 & High & 378 & 0.4 \\
\hline Age & 405 & 0.4 & Increased & 7 & 0.7 & Health & 55 & 0.4 & Syphilis & 345 & 0.4 \\
\hline Women & 396 & 0.4 & Progression & 7 & 0.7 & Negative & 55 & 0.4 & Methods & 332 & 0.4 \\
\hline Gay & 388 & 0.4 & Classic & 7 & 0.7 & High & 55 & 0.4 & Participants & 331 & 0.4 \\
\hline
\end{tabular}

AIDS: acquired immunodeficiency syndrome; HIV: human immunodeficiency virus; MSM: men who have sex with men.

The compiled data confirmed that the gerontological field studies were not unrelated to the epidemic effects, generating a permanent and progressive wave of research since the 1980s. From a thematic perspective, the data revealed the impact of the HIV/AIDS epidemic, which has progressively reverberated into at least 51 subareas of research indexed in the Web of Science database, gathering production on health, biological, social, and technological sciences.

Thus, the wave of studies on HIV/AIDS was quantitatively greater than the studies on gays and lesbians, which started after the so-called Sexual Revolution in the mid-1960s, and associated to relevant socio-anthropological and qualitative researches in Brazil, in the USA, and in the UK. However, there is a difference between these countries: while socio-anthropological studies sought to combat discrimination and stigma, at least in part, health and medicine research responded to the beginning of sexual panic by contributing - even unintentionally - to new forms of sanitation, control, and monitoring of the populations considered exposed 38 .

From the earliest medical and media publications in North America and Europe, issues concerning the foundations of AIDS have not only dealt with clinical aspects, but also with complex moral and social issues $33,34,35,36,38$. Moreover, AIDS was among the epidemic diseases of the past and is now one of the modernity chronic diseases, which converges to a biological problem and with psychosocial etiology, recreating an epidemiological panic from a supposed global threat.

"As others have noted, discourses about AIDS have consistently overflowed with moralizing stories. Initial medical and mainstream media reports were premised on a heavy dose of homophobic sensationalism about 
Table 2

Association analysis between the most frequent terms in the abstracts. Brazil, United States, and United Kingdom, 1990 to September, 2018.

\begin{tabular}{|c|c|c|c|c|c|c|c|c|c|}
\hline \multicolumn{2}{|l|}{ HIV } & \multicolumn{2}{|l|}{ Men } & \multicolumn{2}{|l|}{ MSM } & \multicolumn{2}{|l|}{ Sex } & \multicolumn{2}{|l|}{ Among } \\
\hline Negative & 0.36 & Sex & 0.26 & Among & 0.35 & Partners & 0.32 & MSM & 0.35 \\
\hline Positive & 0.36 & Gay & 0.26 & HIV & 0.33 & Men & 0.26 & Prevalence & 0.29 \\
\hline MSM & 0.33 & Reported & 0.24 & Background & 0.28 & Unprotected & 0.24 & HIV & 0.27 \\
\hline Risk & 0.30 & Risk & 0.24 & High & 0.28 & Reported & 0.23 & Conclusions & 0.24 \\
\hline Testing & 0.29 & Among & 0.20 & Prevalence & 0.27 & Last & 0.23 & Methods & 0.24 \\
\hline Infection & 0.28 & Glasgow & 0.20 & Infection & 0.25 & Married & 0.23 & Infection & 0.21 \\
\hline Among & 0.27 & HIV & 0.19 & Black & 0.24 & Exchanged & 0.23 & Sex & 0.21 \\
\hline Prevention & 0.27 & African & 0.19 & Tested & 0.22 & Among & 0.21 & Background & 0.21 \\
\hline Infected & 0.26 & Symbol & 0.19 & China & 0.21 & Male & 0.21 & Conducted & 0.21 \\
\hline Test & 0.26 & Unusual & 0.19 & Methods & 0.21 & MSM & 0.21 & Men & 0.20 \\
\hline Status & 0.26 & Anal & 0.18 & White & 0.19 & Reporting & 0.21 & Associated & 0.20 \\
\hline High & 0.22 & Ethnic & 0.18 & STD & 0.19 & Behaviors & 0.20 & Regression & 0.20 \\
\hline Incidence & 0.21 & London & 0.18 & Billion & 0.19 & Drugs & 0.19 & Sectional & 0.20 \\
\hline Diagnosed & 0.21 & Self & 0.17 & Prevented & 0.18 & Past & 0.19 & Annualized & 0.20 \\
\hline Transmission & 0.20 & Conclusion & 0.17 & QALY & 0.18 & Selling & 0.19 & $\mathrm{HCV}$ & 0.19 \\
\hline Antiretroviral & 0.20 & Status & 0.17 & Mixing & 0.18 & Wives & 0.19 & Accordance & 0.18 \\
\hline Men & 0.19 & Behavior & 0.17 & Expensive & 0.18 & Receptive & 0.18 & Advisory & 0.18 \\
\hline Viral & 0.19 & Programs & 0.17 & Favorably & 0.18 & Risk & 0.18 & Committee & 0.18 \\
\hline Black & 0.19 & Brighton & 0.17 & Horizon & 0.18 & Money & 0.18 & Conjugate & 0.18 \\
\hline Unknown & 0.19 & Denies & 0.17 & Interim & 0.18 & MSMW & 0.18 & Meningococcal & 0.18 \\
\hline
\end{tabular}

HCV: hepatitis C virus; HIV: human immunodeficiency virus; MSM: men who have sex with men; MSMW: men who have sex with men and women; QALY: quality-adjusted life year; STD: sexually transmitted diseases.

gay male sexual practices, foregrounding social taboos such as anal sex, anonymous sex, and frequent sex with multiple partners. The media, in particular, focused on the most stunning and dramatic cases of gay men with histories of over one thousand sexual partners while ignoring those whose sexual histories were more conventional. Their hysteria reflected and reinforced dominant discourses that equated homosexuality and homosexuals with disease and perversion" 39 (p. 231).

The panic caused by anal sex among men emerges as a casualty transmission cofactor, since it associates a practice with a potential exposure to the virus $33,34,35,36,38,39$. In the analyzed production the term appeared in the 1980s, as shown in Figures 3 and 4, and has remained until recent publications, alongside "MSM", "sex", "among”, and "men”. Thus, the preventive device articulated internal and external categories to the medical-gerontological field, merging knowledge and representations from the many areas of research. Moreover, these categories worked as "predictive biomarkers of sexuality", which representations and symbology were not restricted to the fields of virology, pathology, and epidemiology, but embraced an ambiguous discourse, equally concerned with the definition and stigmatization of subjects and subjectivities.

Sander L. Gilman 34 considered that the epidemic spectrum - similar to syphilis in the past formed an aggregation of visual materials and printed publications, which images reflected a sense of bodily degradation, physical debilitation, skinniness, and death. These aspects are similar to the images of old age, available in the social imaginary and in part of the scientific literature, especially after the 1980s, with a significant increase in studies on HIV and on sex between men.

"The New York Times in 1985 (and subsequently), was full of articles on the anxiety of health workers who treated AIDS patients. For the readers of the Times, this anxiety coincided with the general public's anxiety regarding the transmission of the disease. By 1985, the significance of the single male patient for the readers of The New York Times was self-evident: the patient as a homosexual male" 34 (p. 258). 
With the articulation caused by AIDS in the production of gerontological knowledge and in the present maintenance of the emerged representations of the past - mainly in the late 1980s and increasingly from the 1990s, as the data of the abstracts corroborated - this study considered three complementary lines of arguments, which are the following: (a) the continuous and lasting effect of the AIDS panic; (b) the role given to the chronic diseases in contemporary times; and (c) the increasing longevity of people living with HIV/AIDS, based on public and/or private antiretroviral cocktail policies, nutritional supplementation, and prevention strategies.

Starting from item (a), regarding the continuous and unresolved effect of the AIDS panic, the initial years that involved the discovery and dissemination of the so-called acquired immunodeficiency syndrome - roughly between 1981 and 1986 - followed a historical period in which homosexual subjects were socially conceptualized as psychiatric patients, who had a peculiar type of disorder $33,34,35,36,38$.

In the first edition of the Diagnostic and Statistical Manual of Mental Disorders (DSM-I), published in 1952, homosexuality was included among sociopathic personality disorders, such as a sexual deviance involving pathological behavior. In the second edition of the DSM-III, published in 1968, the category of sociopathic personality disorders no longer appeared, but homosexuality continued as a sexual deviance, with homosexuals described as incapable of having "normal" sexual behavior 33,34. Only in 1973, and under protest from gay activists and with psychiatrists' support, the directors' board of the American Psychiatric Association withdrew homosexuality as a mental illness diagnosis 40.

From the production perspective, the research titles that referred to homosexuality as a psychiatric problem continued to grow until the 1980s, despite the movement of depathologization of samesex relations until a decade after the alteration of the DSM-III. In summary, even after the withdrawal of homosexuality from the list of psychiatric disorders, in the 1970s studies still dealt with terms such as "mental", "psychiatric", and "patients", whereas in the 1980s, on the other hand, there was a coexistence between the association of homosexuality and "psychiatric" with other biomarkers, mostly from the field of epidemiology, which sought to associate same-sex relations to "sarcoma", "kaposis", "anal", "men", "homosexual", "mortality", and "lesbians". Then, these markers were analyzed in more depth, and lasted progressively to the present, as can be seen in the comparison by decade of the analyzed production from 1970 to 2010.

Pelúcio \& Miskolci 40 argued that the transition period from the psychiatric to the epidemiological perspective marks a process of repathologization of the homosexual desire, which hardened during the AIDS spread and intensified at the peak of deaths, in which the desire and homoerotic relations were no longer associated to a question of mental order, but to a problem of transmissible and chronic nature, leading to the construction of supposedly threatening moral panic, harmful to the sexualsocial order of the period.

"The way public health dealt with the epidemic at its beginning, which led to the emergence of 'AIDS' as a bioidentity that, after receiving political treatment, began to gather 'people living with AIDS' into demands for public policies, in which the Foucauldian health paradox became eloquent. Through discursive procedures, epidemiological identities led to behaviors regulation (not only sexual), thus conforming new subjectivities marked by 'self-evaluation" 40 (p. 131).

According to Michel Foucault 41 and as a result of the union between psi and (bio)medical knowledge, this epidemiological perspective influenced the gerontological knowledge production and served as support for future studies on sexuality, medication, and viral control. This occurred simultaneously to the prevention mechanisms and treatment of the sexually transmitted disease (STD), which is confused with the (homo)sexual orientation itself.

Rose 5 considers that modern ways of tracking and life management in contemporary biomedical sciences have led to a coalition between market imperatives and the creation of new knowledge, since the interest in AIDS, at least in the USA and in the UK, comes from studies funded by private companies interested in commercializing biopharmaceutical techniques and products to mitigate the effects caused by the immune suppression of AIDS, such as Gilead Sciences, Inc., which funds research and studies in North America, Europe, and Australia. As Rose 5, this study considered that the association between aging, disease, technology, science, and commerce has caused a growing and inescapable responsibility for the management of one's life, or life itself 42 . 
The contemporary ways of managing and inspecting issues regarding health-disease processes are deeply embedded in dynamics that integrate pathological concepts with the social experience with past panics caused by major epidemics. Biomarkers produced from the AIDS panic, on the other hand, are also chronic categories of knowledge production and collective recognition, especially when analyzing the role of chronic diseases since the last century in different areas of research. In Latin America and mainly in Brazil, negative perspectives on homosexuality have been scientifically projected when receiving the theories from Richard von Krafft-Ebing, Carl F. Otto Westphal, and Cesare Lombroso; these theories regarded notably the eugenic views of human sexuality and same-sex relations in the late 19th and early 20th centuries. Anyhow, the association between homosexuality and pathology is not a recent issue in the Brazilian science, as discussed in the book Homossexualismo $e$ Endocrinologia ("Homosexuality and Endocrinology"), authored by the Brazilian medical criminologist and anthropologist Leonidio Ribeiro (originally published in 1935) 43,44,45.

According to the second line of argument proposed (b), the emphasis given to the HIV/AIDS epidemic is due to an epidemiological and demographic transition model, which is widely discussed in the collective health disciplines. The historical milestone varies according to the specific economic and social aspects of each country.

George W. Leeson 46 argues that the centrality given to chronic diseases in modernity happened due to the way countries have dealt with the shift in population geography, which began in the nineteenth century in developed national contexts, and which has led to a progressive increase in life expectancy rates and a prevalence of chronic diseases to the detriment of those with infectious and contagious etiologies. Leeson 46 and Harper 47 considered that the combined decline in mortality and fertility, on a global scale precisely at the end of the 20th century, propitiated a structural change in the world demographic dynamics. There was not only a perspective change concerning life expectancy and longevity, but also a union between treatable and permanent conditions of pathologies, an increase in comorbidities and cohorts of people over 60 years of age, modification of mortality patterns, and increasing incidence of chronic diseases.

A historical milestone that integrates the increasing survival of people with HIV/AIDS could be considered from the demographic perspective, consisting of the antiretroviral therapy provision through HAART (highly active antiretroviral therapy), from mid-1996/1997. According to the collected data, there was an increasing use of terms related to identifying and monitoring AIDS, notably from "testing", "positive", "negative", and "status". These terms also reflect an increase in policies focused on people living with HIV and who, since the availability of the HAART, have had a considerable increase in life expectancy, even when compared with the life expectancy of uninfected persons.

Thus, this study concluded that one of the explanations for the predominance and permanence of AIDS in gerontological production since 1980 is due to the demographic and epidemiological transformations of the last century, concerning the manner in which the epidemic was assimilated and reproduced by gerontological research focused on chronic diseases in different countries and in the "exposed groups", incorporating a health agenda aimed at the treatment and control of populations considered at "risk", which included homosexuality - for social and historical reasons around a moral panic 48. Furthermore, there has been a substantial increase in the digital indexing of articles and academic essays, which may have also influenced the increase in global production in quantitative terms, since the academic literature has been directly affected by editorial policies focusing on dissemination through online repositories, and the expansion of the commercial Internet in the late 1990s, enabling the access to articles and manuscripts worldwide.

\section{Conclusions}

The production that has become gerontological since the mid-1970s already emerges in the context of the depsychiatrization of homosexuality (withdrawal from the International Statistical Classification of Diseases and Related Health Problems - ICD - in 1973), therefore - purposely or not - not connected to the subject of mental health. However, this distanced the production of homosexual aging from important themes, such as the consequences of continual exposure to forms of discrimination and 
prejudice, and - as the data corroborate - brought it closer to an understanding of homosexuality as an epidemiological issue, mainly associated to gender and to the risk of contracting STDs.

According to the Web of Science database, from the 1990s onwards, notions of old age that shaped scientific descriptors in health science production regarding homosexual aging focused on the male HIV/AIDS epidemic and were linked to the epidemiological threat and treatment of biological issues. Therefore, the scientific representations produced biomarkers of sexuality, which are prominent for the prevalence of the following descriptors: "men", "MSM", "sexual", and "risk". Other expressions of homosexuals' desire and social life were removed from the gerontological literature.

Moreover, the focus on homosexual men shows how gerontological production has developed generically by neglecting due attention to lesbian women, as well as trans or intersex people. Homosexual old age in scientific production has been presented as basically male and, in terms of sexuality, reproduces stereotypes reducing it to sexual practices, hence the emphasis on the "risk" of contracting STDs or specifically the HIV. Thus, homosexual old age portrayed by scientific studies is not recognized in its affective dimension, repeating mainly negative biomarkers, which meanings still reiterate the social representations about same-sex relations with the behavior of "risk", "cancer", "infection", "stigma", "virus", and "epidemic".

Given the data and conclusions, this study highlights the need of establishing other comparative parameters, especially regarding the gerontological production on sexuality in general, to know if what happened in terms of old age representation in studies focusing on homosexuality is also common to the heterosexual segment.

Regarding the findings of this study, three methodological limitations are highlighted: (i) since this study used data on the production of the Web of Science database, it is foreseeable that a significant amount non-digitized studies have been omitted from the collected articles; (ii) these not collected studies and therefore not analyzed, are largely the production of the 1960s, 1970s, and 1980s, which prevented the creation of word clouds and comparative tables that would ease the more accurately recognition of the influence of psychiatrization of health relations and the frequency of biomarkers from the psychiatry and psychology field; finally, (iii) so as not to separate production between the three countries, the data may hide some particular nuances in each context, given that more than half of the collection came from the United States (462/839); and this may have influenced on the analysis, reflecting more the US reality.

\section{Contributors}

J. P. Ferreira contributed to the writing, review, normalization and sociological discussion of the main topics. R. Miskolci contributed to the writing, coordination of the proposal, critical review, and discussion of the main topics.

\section{Additional informations}

ORCID: João Paulo Ferreira (0000-0003-01159032); Richard Miskolci (0000-0002-6405-5591).

\section{Acknowledgments}

The authors acknowledge the valuable support given by the São Paulo Research Foundation (GN 17/23665-9; 19/10677-4) and by the Brazilian Graduate Studies Coordinating Board (GN 23038.001024/2018-91), as well as the Harvard Department of the History of Science, the Radcliffe Institute for Advanced Study, and the Arthur and Elizabeth Schlesinger Library. Furthermore, the authors acknowledge the contributions to this study of Paul Higgs (University College London), Karen Lowton (University of Sussex), Sarah S. Richardson (Harvard University), Guita Grin Debert (Universidade Estadual de Campinas), Priscila Martins Medeiros (Universidade Federal de São Carlos), Suzanne Kirschner (College of the Holy Cross), Marcia C. Inhorn (Yale University), and Lawrence Cohen (University of California - Berkeley). 


\section{References}

1. Hostetler A. Old, gay, and alone? The ecology of well-being among middle-aged and older single gay men. In: Herdt G, De Vries B, editors. Gay and lesbian aging: research and future directions. New York: Springer; 2004. p. 143-76.

2. Rosenfeld D. The changing of the guard: lesbian and gay elders, identity, and social change. Philadelphia: Temple University Press; 1999.

3. Goltz D. Queer temporalities in gay male representation: tragedy, normativity, and futurity. New York: Routledge; 2010.

4. Henning CE. Gerontologia LGBT: velhice, gênero, sexualidade e a constituição dos "idosos LGBT". Horizontes Antropológicos 2017; 23:283-323

5. Rose N. A política da própria vida: biomedicina, poder e subjetividade no século XXI. São Paulo: Paulus; 2013.

6. Fischer MM. Emergent forms of life and the anthropological voice. Durham: Duke University Press; 2003.

7. Novas C, Rose N. Genetic risk and the birth of the somatic individual. Econ Soc 2000; 29:485-513.

8. Haraway D. A cyborg manifesto: science, technology, and socialist-feminism in the late twentieth century. In. Haraway D, editor. Simians, cyborgs and women: the reinvention of nature. New York: Routledge; 1991. p. 149-81.

9. Novas C. The political economy of hope: patients' organisations, science and biovalue. Nottingham: Nottingham University Press; 2001.

10. Herring J, Ciaran R, Weinberg D, Withington $P$. Intoxication and society: problematic pleasures of drugs and alcohol. London: Palgrave; 2013.

11. Gilleard C, Higgs P. Ageing, corporeality and embodiment. London: Anthem Press; 2013.

12. Ortega F. O corpo incerto: corporeidade, tecnologias médicas e cultura contemporânea. Rio de Janeiro: Garamond; 2008.

13. Beauvoir S. La veillesse. Paris: Gallimard; 1970.

14. Debert GG. A reinvenção da velhice: socialização e processos de reprivatização do envelhecimento. São Paulo: Edusp; 1999.

15. Cohen L. No aging in India: Alzheimer's, the bad family, and other modern things. Berkeley: University of California Press; 2000.

16. Cowgill D, Holmes L. Aging and modernization. New York: Appelton-Century-Crofts; 1972.

17. Sarah F. Stem cells R us: emergent life forms and the global biological. In: Ong A, Collier SJ, editors. Global assemblages: technology, politcs, and ethics as anthropological problems. New Jersey: Blackwell Publishing; 2005. p. $59-78$.

18. Cruikshank M. Lavender and gray: a brief study of lesbian and gay aging studies. J Homosex 1990; 20:77-87.
19. Frankis JS, Flowers P. Public sexual cultures: a systematic review of qualitative research investigating men's sexual behaviors with men in public spaces. J Homosex 2009; 56:861-93.

20. Gagnon J, Simon W. Sexual deviance. New York: Harper and Row; 1973.

21. Kelly J. The aging male homosexual: myth and reality. Gerontologist 1977; 17:328-32.

22. Kimmel DC. Adult development and aging: a gay perspective. J Soc Issues 1978; 34:113-30.

23. Laner MR. Growing older male: heterosexual and homosexual. Gerontololgist 1978; 18:496501.

24. Weinberg MS. The ageing male homosexual. Med Aspects Hum Sex 1969; 12:66-72.

25. Weinberg MS, Williams C. Male homosexuals. New York: Oxford University Press; 1974.

26. Friend RA. Older lesbian and gay people: a theory of successful aging. J Homosex 1991; 20:99-118.

27. Hall S. The work of representation. In: Hall S, editor. Representation. Cultural representation and cultural signifying practices. London: Sage; 1997. p. 15-61.

28. Feinerer I, Hornik KR. Package "tm". Vienna: R Foundation for Statistical Computing; 2015.

29. Bouchet-Valat M. SnowballC: snowball stemmers based on the C libstemmer UTF-8 library. Vienna: R Foundation for Statistical Computing; 2014.

30. Fellows I. Package 'wordcloud'. https://cran.rproject.org/web/packages/wordcloud/word cloud.pdf (accessed on 08/Nov/2018).

31. Mingoti SA. Análise de dados através de métodos de estatística multivariada: uma abordagem aplicada. Belo Horizonte: Editora UFMG; 2005.

32. Liu B. Sentiment analysis and opinion mining. San Rafael: Morgan \& Claypool Publishers; 2012.

33. Pollak M. Os homossexuais e a AIDS: sociologia de uma epidemia. São Paulo: Estação Liberdade; 1990.

34. Gilman SL. Disease and representation: images of illness from madness to AIDS. New York: Cornell University Press; 1991.

35. Sontag S. Illness as metaphor and AIDS and its metaphors. New York: Farrar, Straus and Giroux; 1989.

36. Parker RG. Empowerment, community mobilization and social change in the face of HIV/ AIDS. AIDS 1996; 10:27-31.

37. Miskolci R. Desejos digitais. Uma análise sociológica da busca por parceiros on-line. Belo Horizonte: Autêntica; 2017.

38. Perlongher NO. O que é AIDS? São Paulo: Editora Brasiliense, 1987.

39. Gould DB. The shame of gay pride in early AIDS activism. In: Halperin DM, Traub V, editors. Gay shame. Chicago: Chicago University Press; 2009. p. 221-55. 
40. Pelúcio LM, Miskolci R. The prevention of deviance: the aids apparatus and the repatologization of dissent sexualities. Sex Salud Soc 2009; (1):125-57.

41. Foucault M. The birth of the clinic: an archeology of medical perception. London: Tavistock Publications; 1973.

42. Foucault M. The history of sexuality: the care of the self. London: Penguin; 1986.

43. Russo JA, Rohden F, Torres I, Faro L. O campo da sexologia no Brasil: constituição e institucionalização. Physis (Rio J.) 2009; 19:617-36.

44. Tramontano L. Testosterona: as múltiplas faces de uma molécula [Tese de Doutorado]. Rio de Janeiro: Instituto de Medicina Social, Universidade do Estado do Rio de Janeiro; 2017.
45. Stepan NL. The hour of eugenics - race, gender, and nation in Latin America. London: Cornell University Press; 1996.

46. Leeson GW. Drivers of demographic change in the twentieth and twenty-first centuries. In: Harper S, Hamblin K, editors. International handbook on ageing and public policy. Cheltenham: Edward Elgar; 2014. p. 23-35.

47. Harper S. How population change will transform our world. Oxford: Oxford University Press; 2016.

48. Goode E, Nachman BY. Moral panics: the social construction of deviance. Oxford: Blackwell; 1994. 


\section{Resumo}

O estudo faz uma revisão de artigos publicados por autores brasileiros, britânicos e estadunidenses entre 1970 e setembro de 2018 na base de dados Web of Science. Foram utilizadas técnicas de prospecção de textos, com uma análise predominantemente qualitativa, inclusive análise de correspondência e de sentimentos, usando ferramentas do software $R$ (versão 3.5.0). Os resultados revelam a repatologização da homossexualidade na produção de conhecimento gerontológico, incluindo estudos realizados em 51 áreas de conhecimento nos três países. Seguiu-se a despsiquiatrização da homossexualidade durante o auge de óbitos provocados pela aids e o reconhecimento desta como ameaça epidemiológica. $O$ artigo conclui com uma revisão dos biomarcadores coletados, como "sexual", "risco", "HSH" e "HIV/aids", comprovando o impacto progressivo do pânico sexual sobre os estudos de gerontologia, além de associar a aids à homossexualidade masculina.

Homossexualidade; Síndrome de Imunodeficiência Adquirida; Gerontologia; Envelhecimento; Biomarcadores

\section{Resumen}

Este estudio revisó artículos realizados en Brasil, Reino Unido y en los Estados Unidos desde 1970 a septiembre de 2018 en la base de datos Web of Science. Se utilizaron técnicas de mineración de textos, y predominantemente se realizó un análisis cualitativo, incluyendo análisis de correspondencia y análisis de opiniones, usando las herramientas del $R$ Software (version 3.5.0). Los resultados muestran la repatologización de la homosexualidad en la producción de conocimiento gerontológico. Esto incluye estudios realizados en 51 aéreas de conocimiento en los tres países. A todo ello, le siguió la desiquiatrización de la homosexualidad, durante el pico de muertes causado por el SIDA, y su consiguiente reconocimiento como amenaza epidemiológica. Este artículo finaliza revisando los biomarcadores recogidos, tales como: "sexual", "riesgo", "HSH”, y "VIH/SIDA", lo que prueba el progresivo impacto del pánico sexual en los estudios de gerontología, así como los asociados al SIDA, con la homosexualidad masculina.

Homosexualidad; Síndrome de Inmunodeficiencia Adquirida; Gerontología; Envejecimiento; Biomarcadores
Submitted on 21/Nov/2018

Final version resubmitted on 06/Dec/2019 Approved on 30/Dec/2019 